DOI: https://doi.org/10.32839/2304-5809/2021-4-92-44

УДК 811.111’37

Сапожник I.B., Суродейкіна T.B.

Чернівецький національний університет імені Юрія Федьковича

\title{
СЕМАНТИЧНІ ОСОБЛИВОСТІ ЛСП ВЕГАНСТВО В СОЦІАЛЬНИХ МЕРЕЖАХ
}

\begin{abstract}
Анотація. У поданій статті проаналізовано семантичні особливості англомовного лексико-семантичного поля ВЕГАНСТВО в соціальній мережі Інстаграм. Виявлено, що у складі досліджуваного поля безперечно переважають лексеми на позначення їжі (49\%), приблизно однаково представлено поля LIFESTYLE, FASHION та ANIMAL PROTECTION (11\%, 11\% та 10\% відповідно). Решта підполів містить набагато менше одиниць, проте, це не зменшуе їхньої значущості у досліджуваній темі. Так, у лексико-семантичному підполі FOOD користь від веганських продуктів ілюструеться і пропагується в мережі Інстаграм набагато частіше, ніж шкідливі прояви тваринної їжі. LIFESTYLE переважно розкривае користь способу життя, що пропагуе веганство, і базуеться здебільшого на тенденції до захисту тварин від насильницького утримання через відмову споживання їжі тваринного походження. Лексико-семантичне підполе FASHION позначає нові веганські види шкіри та описують взуття, вироблене з біоматеріалів. У ЛСП ANIMAL PROTECTION кількісно переважають лексеми на позначення страждань тварин на фермах над лексемами на позначення користі від веганства.
\end{abstract}

Ключові слова: веганство, лексико-семантичне поле, підполе, соціальні мережі, тварини.

Sapozhnyk Iryna, Surodeikina Tetiana Chernivtsi National University named after Yurii Fedkovych

\section{SEMANTIC PECULIARITIES OF LEXICAL-SEMANTIC FIELD VEGANISM IN SOCIAL NETWORKS}

Summary. Veganism as a modern trend can be defined not only non-consumption of animal products but also as a whole human lifestyle aiming at lowering carbon dioxide emission and red meat consumption as a cause of numerous serious diseases, consequently, launching a drop in the size of farming lands followed by deforestation decrease. Thus, the importance of such a notion as 'veganism' and its vocabulary stipulates the improvement of the whole ecological situation on the planet Earth. In spite of its significance, the phenomenon of veganism has not found its proper investigation in linguistic literature yet. In this work, we are making an attempt to outline the main current views available. The given article aims at revealing semantic peculiarities of the lexical- semantic field VEGANISM on the pages of a social network Instagram. In the process of our investigation, we have subdivided the field under analysis into a range of subfields consisting, in their turn, of lexical semantic groups and rows. It has also been found out that food lexemes proved to be dominant comprising almost half of all the material under study. Such fields as LIFESTYLE, FASHION, and ANIMAL PROTECTION are represented with an approximately equal number of lexemes $(11 \%, 11 \%$, and $10 \%$ correspondingly). Other fields turned out to be much less frequent, which, however, does not underestimate their significance in the topic researched. Thus, FOOD field reveals the key benefits of vegan products, while the vegan LIFESTYLE is predominantly based on the lexemes denoting total refusal to consume animal food. Vegan FASHION (101 приклад) illustrates new vegan types of leather and introduces footwear and accessories made of innovative biomaterials. ANIMAL PROTECTION field describes animal suffering on fur, milk, and meat farms and suggests a way to eliminate it. MEDICINE reflects the advantages of a vegan diet in the recovery process. BUSINESS field shows vegan innovations in the restaurant business introducing new menu options and service perspectives. CELEBRITIES field is represented by outstanding world film and sports stars, as well as politicians turning to the vegan lifestyle and widely promoting it.

Keywords: veganism, lexical-semantic field, subfield, social networks, animals.

$\Pi^{2}$ остановка проблеми. Веганство визначається не просто як процес сироїдіння, а й увесь спосіб життя людини, який сприяє зменшенню викидів парникових газів у атмосфреру Землі, відмова від споживання червоного м'яса, як причини багатьох хвороб, відповідно, зменшення обсягу земельних ділянок під фрермерство, припинення в результаті цього вирубки лісів, тощо. Тобто, детальне вивчення такого поняття як "веганство» та лексики на його позначення сприятиме покращенню екологічної ситуації усієї планети.

Аналіз останніх досліджень і публікацій. Не дивлячись на глобальну популярність веганства, грунтовні лінгвістичні дослідження та публікації на цю тему не є численними. Так, наприклад, А.А. Луценко аналізувала англомовну термінологію вегетарианства в зіставному аспек- ті [4], онлайн новини BBC News регулярно розміщують дописи з теми веганства [2], численніші статті на тему користі чи шкоди цього явища для людського організму розміщенні у різноманітних медичних онлайн журналах, наприклад, MEDJOURNAL.COM [1].

Виділення не вирішених раніше частин загальної проблеми. Таким чином, досліджуване поняття ще не стало об'єктом детального аналізу зарубіжних і вітчизняних науковців у сорері мовознавства.

Мета статті - розкрити семантичні особливості ЛСП ВЕГАНСТВО в соцмережі Інстаграм.

Виклад основного матеріалу. Поняття «веганство» та "вегетаріанство» базуються на ідеях, закладених ще за 600-500 років до н.е. Виокремлюються два центри-першопочатку цих практик - Давня Греція та Індія; в першому ці 
поняття пов'язувалися з протистоянням жорстокості та вбивству, в другому - 3 ідеєю переселення душі (реінкарнації).

У Давній Греції ці ідеї пов’язані з іменем Піфрагора, чия фрілософія мала на меті особливу дієту відмову від м'яса будь-яких живих істот, а також бобових, оскільки їх вживання заважало мисленневому процесу та досягненню істини [5, с. 74-75].

В Давній Індії м'ясо вживали рідко, передусім для релігійних обрядів та жертвоприношень. Найбільш поширеною відмова від м'яса стала після появи буддизму та індуїзму [8].

Ця давньоіндійська традиція зазвичай супроводжуеться такими практиками як йога та медитація, направлених на пошук гармонії з оточуючим світом, Богом та самим собою.

В Свропі не всі ті, хто підтримують ідеї ненасилля до усього живого наразі погоджуються із індійськими традиціями, тому створюють нове західноєвропейське вегетаріанство та веганство.

Звертаючись до Біблії, бачимо, що деякі її місця свідчать про те, що дванадцять апостолів були вегетаріанцями, та що перші християни утримувалися від уживання м'яса 3 позищій чистоти та милосердя [3], слідуючи Шостій заповіді «Не вбий». В цьому тлумаченні вбити можливо все, що містить життя, отже, тварин, згідно заповіді, вбивати також не можна. Старий Заповіт на додачу містить багато доводів на користь сироїдіння.

За визначенням В. Безшейка, вегетаріанська diema - «це вид режиму харчування, який передбачає відмову від споживання м'яса та м'ясних продуктів, включаючи м'ясо крупної рогатої худоби, птищі, риби та/або плоть будь-якої іншої тварини. Цей режим харчування поступово набирає великої популярність у всьому світі. Так, одна із найбільших вегетаріанських спільнот живе в Індії, також великий відсоток осіб, які притримуються цієї дієти, проживає Свропейських країнах, наприклад, у Італії, Великобританії, Німеччині, Нідерландах» [1].

Більш жорсткий патерн харчування, веганство, передбачає повну відмову від тваринних продуктів харчування, включаючи молоко, яйця птищі тощо.

Цей термін увели в обіг в сорокові роки 20 століття 3 ініціативи засновника Британського товариства веганів Дональда Вотсона як слово, яке описуе немолочних вегетаріанців [2].

«Більшість термінів, таких як пескетаріанец, фрріган і лакто-ово-вегетаріанець, створені для того, аби ідентифікувати спосіб харчування, в той час як веганство пов'язане не тільки з їжею, це принцип життя, спрямований на скорочення будь-якого виду експлуатації тварин», - пояснюе Рауль з The Vegan Corner, першого профресійного каналу кулінарії на YouTube, повністю присвяченого рослинній кухні.

Однак, вегани ризикують недоотримати необхідні поживні речовини, яких потребує організм, наприклад, вітамін В12, який міститься тільки в продуктах тваринного походження. Тому так важливо планувати свій раціон.

Отже, веганство - це спосіб життя, принципи якого були закладені ще у Давній Індії та Греції, і пов'язані вони з відмовою від м'яса та іших продуктів тваринного походження заради гуманності та слідування релігійним нормам.
Для аналізу лексики на позначення веганства, ми опрацювали 270 дописів Інстаграм сторінки Totally Vegan Buzz [9] з січня по квітень 2021. Спільнота щоденно розміщувала декілька статей на тему веганства, описуючи різні його сфери. Методом суцільної вибірки ми виписали 933 слова і словосполучення на позначення цього поняття.

Тепер здійснимо спробу побудувати лексикосемантичне поле ВЕГАНСТВО на матеріалі Інстаграм сторінки Totally Vegan Buzz [там само].

Спочатку проведемо компонентний аналіз лексеми vegan та veganism, як похідне від нього, для виділення їх основних сем на базі 5 тлумачних словників англійської мови: Cambridge Dictionary, Oxford Advanced Learner's Dictionary, Merriam-Webster Dictionary, Collins Dictionary, Macmillan Dictionary. Більшість словників подають єдине значення лексеми vegan, як особи, що не вживає продуктів тваринного походження. Merriam-Webster Dictionary уточнюе це значення через поняття "strict vegetarian». Collins Dictionary також подає його прикметникові значення. Таким чином, усі аналізовані словники містять єдине значення лексеми veganism, тобто вона $є$ моносемантичною і становить ядро досліджуваного поля. Усі його елементи можуть бути пояснені за допомогою ядерної лексеми - домінанти ЛСГ ВЕГАНСТВО, наприклад:

- aquafaba - "the water from cooked beans, used instead of egg whites in vegan cooking" [6];

- Sylvania - "a mushroom derived vegan leather" [9];

- seitan - "a food made from wheat that is high in protein and that is used in vegan cooking instead of meat" [6].

Розглянемо також синонімічні та антонімічні поняття веганству для подальшого включення у склад поля. Так за словником Merriam-Webster [7] синонімами є наступні лексеми : herbivore, insectivore, vegetarian, а антонімом carnivore.

Таким чином, ми аналізуватимемо усі слова та словосполучення, що позначають поняття протилежні або синонімічні animal products, such as meat, fish, eggs, cheese, or leather.

Виділивши лексико-семантичні підполя food, cosmetics, fashion, celebrities, business, lifestyle, medicine, animal protection, розглянемо їхні особливості.

Оскільки веганство передусім пов'язане 3 невживанням продуктів тваринного походження, розпочнемо з аналізу лексико-семантичного підполя FOOD. Воно виявилося найбільшим за кількістю елементів у ньому - 462 слова та словосполучення. Причому 436 з них е лексемами на позначення корисних продуктів без тваринного білка - лексико-семантична група HEALTHY FOOD, наприклад: alternative protein, vegan steak, dairyfree chocolate, healthy diet, organic cocoa, veggie burgers, seitan chichen, asada tacos тощо.

Решта 26 одинищь теж на позначення їжі, але шкідливої, тваринного походження UNHEALTHY (ANIMAL-UNFRIENDLY) FOOD, наприклад: francken-chicken, meat from slaughtered fur animals, cholesterol kills, barbaric foie gras.

3 наведених прикладів видно, що користь від веганських продуктів ілюструеться і пропагується в мережі Інстаграм набагато частіше (в 16 разів), ніж шкідливі прояви тваринної їжі. 
Як вказувалося у словниковій дефініції, поняття "веганство» - це не лише невживання їжі тваринного походження, а й спосіб життя. Отже, розглянемо лексико-семантичне підполе LIFESTYLE, яке складається зі 100 одиниць. Як і підполе FOOD, воно розділяеться на антонімічні групи: HEALTHY LIFESTYLE/ UNHEALTHY LIFESTYLE, базуючись на невживанні/вживанні їжі тваринного походження, згідно авторів дописів, що досліджувалися. Логічним чином, прояви здорового способу життя проілюстровані набагато краще, ніж протилежного йому. Наведемо приклади:

- HEALTHY LIFESTYLE (82 одиниці) - never eat meat, wildlife campaigner, go vegan, crueltyfree, avoid meat and dairy products, ditch animal products, go meatless, etc;

- UNHEALTHY LIFESTYLE (18 одиниць) - meat-eater, consume animals, conduct animaltesting, etc. Також, можуть скаржитися, що дотримуватися веганської дієти дорого (expensive diet), не вистачає веганських продуктів у магазинах та ресторанах (lack of suitable options), цей спосіб життя займає забагато часу (too time-consuming).

Синонімами є наступні приклади:

- go vegan, never eat meat, avoid meat and dairy products, ditch animal products, go meatless

Розрізняемо в цьому підполі наступні антонімічні пари:

- never eat meat - consume animals;

- cruelty-free - conduct animal-testing.

Як і в попередньому підполі, користь способу життя, що пропагуе веганство, представлена набагато більше (у п'ять разів) і базуеться переважно на тенденції до захисту тварин від насильницького утримання через відмову споживання їжі тваринного походження.

Лексико-семантичне підполе FASHION представлене 67 одиницями групи LEATHER, які описують різноманітні види шкіри нетваринного походження, що є розроблені і використовуються такими провідними світовими брендами, як H\&M та UGG. Саме перший 3 них дебютував 3 виробами із кактусової шкіри та нитками з касторової олії. Отже, серед веганських видів шкіри представлені vegan mushroom leather, vegan cactus leather, leather from fruit and fungi. Sylvania - це вид шкіри, розроблений стартапом 3 Каліфорнії, що базуеться на продуктах міцелію. Схожий матеріал Mylo тм також виробляеться з грибниці, що швидко розростається.

Шкіра, вироблена з грибів, позначаеться синонімічними поняттями: mushroom leather, Sylvania, Mylo.

Лексико-семантичне підполе FASHION також містить 34 лексеми на позначення одягу, які ми об'єднали в групу CLOTHES. Вона представлена одиницями, які описують, наприклад, склад веганських чоботів бренду UGG: vegan shoes, carbon-neutral, plant-based material, sugar cane and lyocell fiber." UGGs must go fully vegan", вважає автор допису.

Лексеми vegan та plant-based виражають синонімічне поняття.

Також цікаво, що суперзірка «Гри престолів» Джейсон Момоа запустив лінію веганських кросівок, виготовлених 3 водоростей: vegan sneaker range, organic cotton upper, bloom foam algae insoles, biodegradable cork.
Отже, лексико-семантичне підполе FASHION позначає нові веганські види шкіри та описують взуття, вироблене з біоматеріалів.

Лексико-семантичне підполе ANIMAL PROTECTION складається 3 двох антонімічних груп. Перша з них - на позначення користі від веганства для збереження популяції тварин та доброго для них ставлення, а друга відображає увесь негатив, пов'язаний з промисловим розведенням тварин на м'ясо та хутро. Наведемо приклади.

- VEGANS' ANIMAL PROTECTION (30) broiler welfare, ban fur sales, make fur obsolete, stop using cochineal beetles in lipstick production, replace beetles for carmine, commitment to animal welfare, kidness to animals;South Australia bans single use of plastic items to reduce harm caused to wildlife, more items are added to the banned list;

Так, лексеми ban fur sales та make fur obsolete, як і stop using cochineal beetles in lipstick production, replace beetles for carmine є синонімами.

- ANIMAL SUFFERING (60) - inflict violence, sell suffering, consume animals, animal suffering, animals pumped with antibiotics, animal testing in cosmetics, etc.

Розглянувши ці групи, бачимо, що вони містять антонімічні поняття : animal welfare, kidness to animals з одного боку, та animal suffering з іншого.

Кількісно переважають лексеми на позначення страждань тварин на фермах для привернення уваги читачів до цієї проблеми із закликом припинити це, не носити хутро, не використовувати червону помаду, для виробленя якої нищять тони жуків, що виробляють червоний пігмент, не використовувати косметику, проби якої проводять на тваринах (animal-tested).

Недивним $є$ той фракт, що веганський стиль життя використовуеться і в медищині, лексико семантичне поле якої (MEDICINE) ми розділили на переваги веганства для процесу одужання, та недоліки у недотриманні веганської дієти і продальшому розвитку захворювань. Розглянемо деякі приклади.

- MEDICAL VEGANISM (34) - herbal meals, cure HPV (papiloma virus), hepatitis, stomach ulcer, asthma, breast cancer, infections, etc.; tackle root causes of diseases. 'Lebanon hospital was the $1^{\text {st }}$ to serve only vegan meals to the patients'.

- DRAWBACKS OF NON-VEGAN DIET (30) 'consuming red meat, you are more likely to smoke, drink alcohol, gain weight'. 'Eating meat is linked to a higher risk of heart disease, pneumonia, digestive disorder, diabitis, bowler cancer'.

Легко помітити, що щі групи представлені майже однаковою кількістю лексем, що свідчить про однакову важливість дотримання веганської дієти 3 медичних показань та для запобігання розвитку серйозних хвороб.

Лексико-семантичне підполе BUSINESS. I3 популяризацією веганського способу життя розвилися і нові сфрери бізнесу (60 лексем), пов'язані 3 ним. Так, серед них ми можемо виділити нові напрямки у ресторанному, готельному та модному бізнесі. Наприклад:

- RESTAURANT (36) - fermented food, plantbased menu, vegan restaurant in LA, vegan options in the menu, 100\% vegan menu in a space hotel, Burger king (UK) menu is plant-based, Strarbucks vegan protein box, dairy-free drink, new line of dairy-free, etc; 


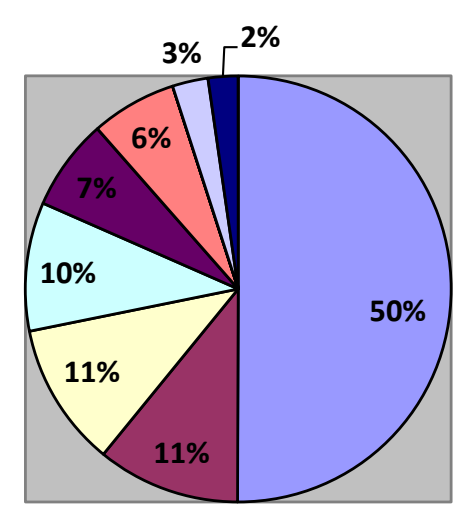

\section{$\square$ food \\ 口 lifestyle \\ $\square$ fashion}

$\square$ animal protection

$\square$ medicine

$\square$ business

$\square$ cosmetics

celebrities

Рис. 1. Порівняльний аналіз кількості лексем у підполях ЛСП ВЕГАНСТВО у соцмережі Інстаграм

Джерело: розроблено авторами

- HOTEL (6) - vegan boutique hotel, plant-based eco-hotel;

- FASHION (12) - team with H\&M, Californian mycelium start-up;

- NEW SHOPS (6) - $1^{\text {st }}$ vegan butcher shop, to bridge the gap for omnivores.

Так, у групі HOTEL спостерігаємо синоніми vegan hotel, plant-based hotel, і схожі у групі RESTAURANT - plant-based menu - vegan menu.

Бачимо, що безперечна перевага серед бізнесових інновацій, пов'язаних із веганством, належить ресторанному бізнесу, в якому тепер з'явилися нові перспективи подачі веганських страв та опції в меню.

Менш представленим є підполе, присвячене косметиці, усього 25 лексем.

Так, оголошено випуск carmine-free, animalfriendly lipstick. Також, фірма Garnier проголосила себе cruelty-free, no animal-testing. Зоозахисники вимагають припинення тестувати на тваринах китайську косметику: hairdyes, freckleremovers, whitening products, sunscreens, antiacne, anti-hair loss.

Найменшим за кількістю лексем (21) виявилося підполе CELEBRITIES, оскільки дописи на цю тему з'являлися на Інстаграм-сторінці найрідше, приблизно раз на тиждень. Втім, це не знижуе значущості інформації, поданої в них, оскільки вона стосуеться дійсно відомих людей, які вирішили повністю чи частково перейти на веганський спосіб життя. До них відносяться, наприклад:

- Lawrence Okolie - непереможний англійський боксер-профессіонал, перший веган, який виборов кубок по версії WBO;
- Gordon Ramsay - британський шеф-кухар, ведучий низки кулінарних телешоу (Masterchef, Hell Kitchen), який після 20 років готування м'ясних страв вирішуе turn vegan;

- Alan Cumming - австралійський актор, який закликаe Starbucks Canada припинити завищувати ціни на non-dairy milk, 0.95 USD overcharge;

- Kamala Harris - перша в історії США темношкірий віце-президент, яка уникає м'ясні та молочні продукти (avoid meat and dairy products), та замовила під час візиту в Лос Анжелесі vegan taco;

- Orlando Bloom - кіноактор фільмів «Пірати Карибського моря», «Володар кілець» тощо , вирішив майже повністю перейти на веганський спосіб життя: following $90 \%$ plant-based lifestyle, plant-based diet, green powders, brain octane oil, porridge and hazelnut milk, goji berries;

- Leonardo di Caprio - також видатний кіноактор, зірка фрільму «Титанік» режисера Джеймса Камерона, навіть підписав угоду з брендом, що випускае веганську їжу: urges to replace 1 beefburger with a walk to help fight climate change; to take $12 \mathrm{mln}$ cars off the road; teamed with vegan food brand (Beyond Meat);

- Joaquin Phoenix - актор, відомий своїми ролями в історичних фільмах, wears pro-vegan hoodie at Golden Globe 2021, animal equality hoodie, strong belief into animal right.

Отже, провідні світові актори, політики, спортсмени все більше звертаються до веганського способу життя і всіляко рекламують його.

Порівнюючи проаналізовані підполя, ми отримали наступні дані, зображені у рисунку 1.

3 рисунку 1 видно, що у складі ЛСП ВЕГАНСТВО на матеріалі дописів із соцмереж (Інстаграм) безперечно переважають лексеми на позначення їжі (49\%), приблизно однаково представлено поля LIFESTYLE, FASHION та ANIMAL PROTECTION (11\%, 11\% та $10 \%$ відповідно). Решта підполів містить набагато менше одиниць, проте, це не зменшуе їхньої значущості у досліджуваній темі.

Висновки і пропозиції. Провівши семантичний аналіз лексем лексико-семантичного поля ВЕГАНСТВО на матеріалі дописів із соцмережі Інстаграм, можемо стверджувати, що воно має розгалужену структуру та охоплюе низку тем, базуючись на яких ми виділили лексико-семантичні підполя, групи і ряди.

Перспективами подальших досліджень може стати вивчення явища веганства в художній літературі, особливості його висвітлення в пресі, також перекладацький аспект або його культурологічні складники.

\section{Список літератури:}

1. Безшейко В. Вплив вегетаріанства та веганства на стан здоров’я та тривалість життя. Психосоматична медицина та загальна практика. URL: https://uk.e-medjournal.com/index.php/psp/article/view/40 (дата звернення: 14.04.2021).

2. Вегани: які бувають, що їдять, чи носять одяг з вовни. BBC NEWS Україна. URL: https://www.bbc.com/ ukrainian/features-46892614 (дата звернення: 14.04.2021).

3. Вегетарианство в мировых религиях. URL: https://secrethistory.su/page,2,343-vegetarianstvo-v-mirovyhreligiyah.html (дата звернення: 14.04.2021).

4. Луценко А.А. Терминология вегетарианства в английском языке. URL: https://pgu.ru/upload/iblock/23f/Pagesfrom-CH-3_-_115-ekz._55.pdf (дата звернення: 13.04.2021).

5. Ямвлих. О Пифрагоровой жизни / Пер. с древнегреч. И.Ю. Мельниковой. Москва : Алетейа, 2002.75 с.

6. Cambridge Dictionary. URL: https://dictionary.cambridge.org (дата звернення: 17.04.2021).

7. Merriam-Webster Dictionary. URL: https://www.merriam-webster.com (дата звернення: 17.04.2021).

8. Spencer C. The Heretic's Feast: A History of Vegetarianism. University Press of New England. Hanover, 1996. 216 p.

9. Totally Vegan Buzz. URL: https://instagram.com/totallyveganbuzz?igshid=111j7xaxhki38 


\section{References:}

1. Bezsheiko V. Vplyv vehetarianstva ta vehanstva na stan zdorovia ta tryvalist zhyttia [Vegetarianism and veganism impact on health and life span. Available at: https://uk.e-medjournal.com/index.php/psp/article/view/40 (accessed 14 April 2021)

2. Verhany: yaky buvaiut, shcho yidat, chy nosiat odiah z vovny [Vegans: what types are they, what are their food preferences, do they wear woolen clothes]. BBC NEWS Ukraine. Available at: https://www.bbc.com/ukrainian/ features-46892614 (accessed 14 April 2021).

3. Vehetarianstvo $\mathrm{v}$ svitovykh relihiiakh [Veganism in world religions]. Available at: https://secrethistory.su/ page,2,343-vegetarianstvo-v-mirovyh-religiyah.html (accessed 14 April 2021).

4. Lutsenko A.A. Terminologiya vegetarianstva v angliyskom yazyke [Vegetarian terminology in English]. Available at: https://pgu.ru/upload/iblock/23f/Pages-from-CH-3_-_115-ekz._55.pdf (accessed 13 April 2021).

5. Yamvlih. O pifagorovoy zhizni (2002) [On the life of Pythagoras]. Moscow: Alteya, 75 p.

6. Cambridge Dictionary. URL: https://dictionary.cambridge.org (accessed 17 April 2021).

7. Merriam-Webster Dictionary. URL: https://www.merriam-webster.com (accessed 17 April 2021).

8. Spencer C. (1996)The Heretic's Feast: A History of Vegetarianism. University Press of New England. Hanover, 216 p.

9. Totally Vegan Buzz. URL: https://instagram.com/totallyveganbuzz?igshid=111j7xaxhki38 